\title{
Students' Preferred Characteristics of Learning Environments in Vocational Secondary Education
}

\section{Ingeborg Placklé*}

Educational Sciences, EDWE, Teacher education, IDLO, Vrije Universiteit Brussel Pleinlaan 2, 1050, Brussels, Belgium

Vilderstraat 5, 3500 Hasselt, Belgium

E-mail: Ingeborg.Plackle@vub.ac.be

\section{Karen D. Könings}

School of Health Professions Education, Department of Educational Development and Research, Maastricht University

Universiteitssingel 60, 6229 ER Maastricht, the Netherlands

E-mail: kd.konings@maastrichtuniversity.nl

\section{Wolfgang Jacquet}

Educational Sciences, EDWE, Tandheelkunde, MOND, Vrije Universiteit Brussel Pleinlaan 2, 1050, Brussels, Belgium

E-mail: Wolfgang.Jacquet@vub.ac.be

\section{Katrien Struyven}

Educational Sciences, EDWE, Teacher education, IDLO, Vrije Universiteit

Pleinlaan 2, 1050, Brussels, Belgium

E-mail: Katrien.Struyven@vub.ac.be

\section{Arno Libotton}

Educational Sciences, EDWE, Vrije Universiteit Brussel

Pleinlaan 2, 1050, Brussels, Belgium

E-mail: Arno.Libotton@vub.ac.be

\section{Jeroen J. G. van Merriënboer}

School of Health Professions Education, Department of Educational Development and Research, Maastricht University

Universiteitssingel 60, 6229 ER Maastricht, the Netherlands

Email: j.vanmerrienboer@maastrichtuniversity.nl

\section{Nadine Engels}

Educational Sciences, EDWE, Teacher education, IDLO

Pleinlaan 2, 1050, Brussels, Belgium

Email: Nadine.Engels@vub.ac.be

* Corresponding author 


\begin{abstract}
If teachers and teacher educators are willing to support the learning of students, it is important for them to learn what motivates students to engage in learning. Students have their own preferences on design characteristics of powerful learning environments in vocational education. We developed an instrument - the Inventory Powerful Learning Environments in Vocational Education - to measure students' preferences on characteristics of powerful learning environments in vocational education. We investigated whether student preferences on the design of their learning environments are in line with what is described in the literature as beneficial for learning. Data of 544 students show that the preferences of students support most characteristics of PLEs in vocational education. Looking through the eyes of students, teachers have to challenge their students and encourage them to take their learning in their own hands. Adaptive learning support is needed. Remarkable, students do not prefer having reflective dialogues with teachers or peers.
\end{abstract}

Keywords: secondary vocational education, characteristics of powerful learning environments, student perceptions and preferences, survey 


\section{Introduction}

In the PISA (Programme for International Student Assessment) report entitled Excellence Through Equity: Giving Every Student the Chance to Succeed (2012), the OECD defines equity in education as "providing all students, regardless of gender, family background or socio-economic status, with opportunities to benefit from education (p.13)." Internationally, schools are not meeting the needs of growing numbers of students in secondary education. Especially for those students whose backgrounds have placed them at 'disadvantage', the statistics are disturbing (Smyth and Fasoli, 2007). Considering the strong relation between social background and the extent to which students engage in educational activities, aligning education with the needs of students is an enormous challenge in most countries, especially for vocational education because most of the students with a disadvantaged background follow vocational pathways. Educational engagement could be both an important predictor of achievement at school, and a key preventive factor for underachievement (Walsh and Black, 2009). While disengagement is affected by social background, it is also strongly influenced by school-based factors including instructional strategies, pedagogy, and curriculum (Fullarton, 2002; Marks, 2000; Shernoff, 2014; Walsh and Black, 2009; Willms, 2003). Disengagement hinders growth in literacy and numeracy, and causes passivity or limited investment of effort, underachievement, disruptive behaviour, poor attendance and leaving school (Cole, 2006; Fredricks et al., 2004). These problems tend to be more present in schools with many students from a low socioeconomic status background (OESO, 2012; Smyth and Fasoli, 2007). Shernoff (2014) states that nearly one third of the students say they are bored because they are not sufficiently challenged by education. Meanwhile, teachers have a tendency to lower their expectations in response to student disengagement, resulting in a vicious cycle (Yazzie-Mintz, 2007).

There is strong evidence that a solution to disengagement lies in studentcentred learning environments (Smyth and Fasoli, 2007). Internationally, relatively few schools manage to combine a high number of disadvantaged students and high achievement (Walsh and Black, 2009). These schools do focus on student-centred learning and have a challenging curriculum that connects to the students' lives and the community in which students live. As such, they provide authentic tasks requiring complex thinking and allowing time for exploration, while taking individual differences into account, developing cooperation, communication, negotiation and social competencies, and emphasizing deep understanding and selfregulated learning (Centre for Applied Educational Research, 2002; Kannapel and Clements, 2005; Smyth and Fasoli, 2007). Learning in these environments often takes place in the context of thematic learning communities with high achievement expectations (Shefford, 2014). In a student-centred learning environment student voices regarding their preferences need to be heard. Therefore, the aim of this study is to investigate what students prefer with regard to the design of the learning environment in secondary vocational education. Especially preferences of characteristics of powerful learning environments will be studied.

\subsection{Model for Powerful Learning Environments in Vocational Education}

Student-centred learning environments that emphasize the integration of domainspecific knowledge, and cognitive and emotional self-regulation skills for tackling 
problems and handling situations in everyday life, are usually based on a constructivist epistemology and resort under so-called powerful learning environments (PLEs) (De Corte, 1990). Placklé et al. (2013) have described the characteristics of PLEs in Secondary Vocational Education, with a focus on a newly developed multidisciplinary and integrated course, Project General Subjects (PGS). In PGS functional math, language, and information processing skills are integrated in a course that has a curricular emphasis on life, social, and/or vocational problems, and wherein social resilience and social responsibility are developed at the same time. Characteristics are based on the available literature and endorsed by teacher educators, teachers and students. Figure 1, the Model for Powerful Learning Environments in Vocational Education (PoLEVE; Placklé et al., 2013) gives an overview of these characteristics. The student is situated at the middle, as the centre of teaching and learning.

Characteristics refer to:

- Authentic learning tasks organized in challenging learning pathways

- Opportunities for the development of key competences

- Adaptive learning support

- A positive and safe learning community

We will describe these characteristics in more detail below. 


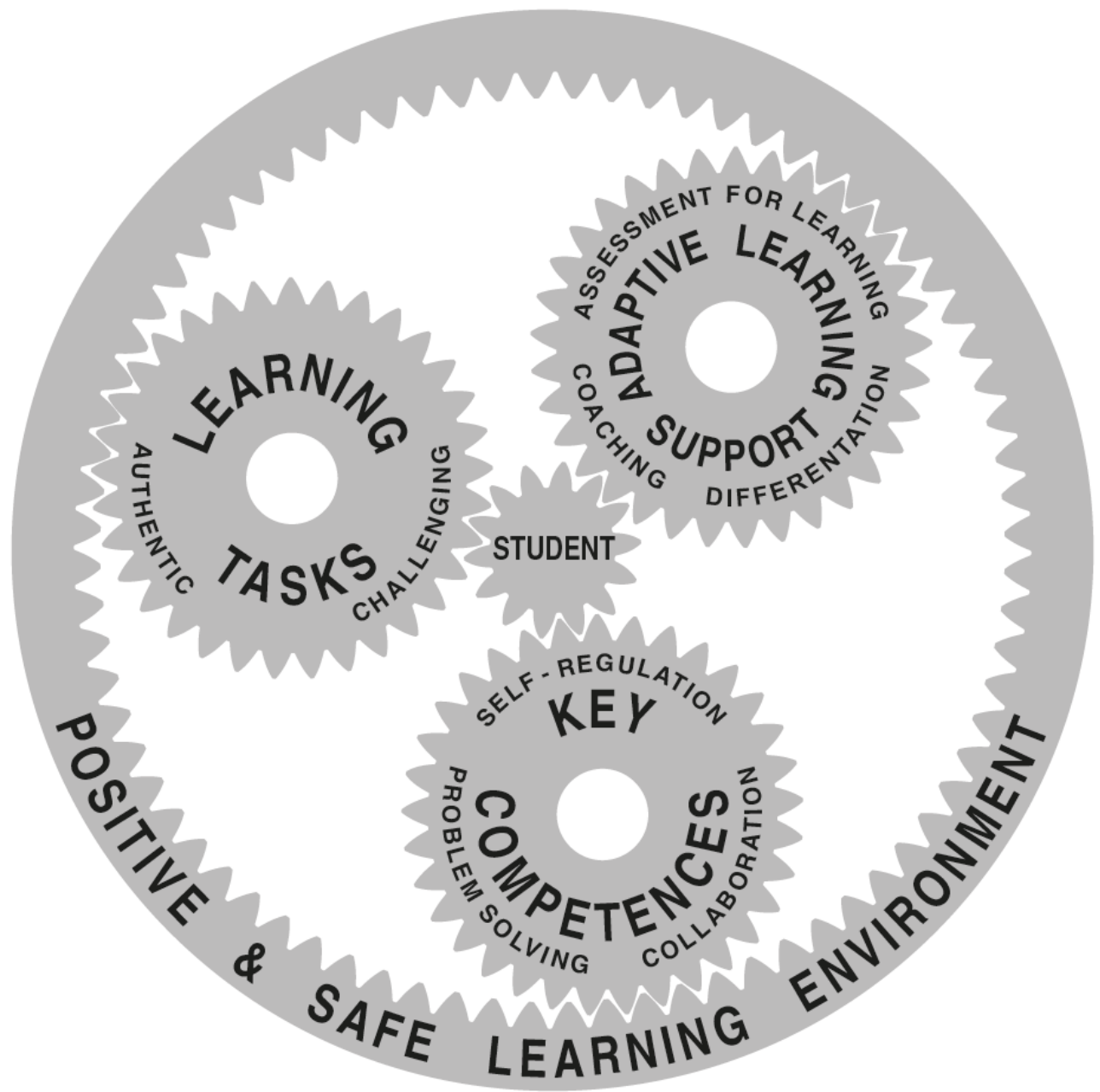

Figure 1: Model for Powerful Learning Environments in Vocational Education (Placklé et al., 2013)

\subsubsection{Authentic Learning Tasks organized in Challenging Pathways}

Attractive education is not 'easy' education, but has to be challenging and meaningful (De Bruijn, 2010). Authentic tasks, preferably performed in realistic contexts can be very challenging and meaningful. Authentic tasks are assignments or problems from daily life and/or from vocational practice. These assignments might need to be redesigned to be applicable in education, but the complexity of the realworld should remain an essential feature of the tasks (van Merriënboer and Paas, 2012). Challenging pathways connect to students' lives (Rumberger, 2012). They present authentic tasks, requiring challenging thought and allowing time for exploration (Smyth and Fasoli, 2007). Authentic tasks, performed in realistic contexts are challenging and meaningful. To design authentic tasks, close cooperation with society and professionals is necessary (De Bruijn, 2012). Students themselves become actively involved in the design of the learning process (Könings et al., 2014; Smith and Blake, 2006). When students are actively involved in learning activities, it is more likely that learning will be meaningful (2012; Van Beek et al., 2014). In this way, the design of these learning environments becomes a shared responsibility of teachers and students. 


\subsubsection{Opportunities for the Development of Key Competences}

Self-regulated learning, collaborative learning and problem solving are characteristics of effective learning processes at the heart of PLEs (De Corte, 2003; Könings et al. 2005). Self-regulated learning implies that students take control over their own learning, including the stipulation of their own personal learning goals -within the framework of their curriculum-, the choice of appropriate learning activities to work on these goals, and reflection on their learning (Boeckaerts et al., 2000; Cleary and Zimmerman, 2004; Kicken et al., 2009). Learning is facilitated when students are engaged in a problem-centred instructional design in which skills are taught in the context of real-world problems. Working in small groups can enhance problem-solving performance and learning (Sears and Reagin, 2013). Nelson (1999) explicitly stipulated the importance of "collaborative problem solving". Working in small groups and within reciprocal relationships, each student has opportunities to participate and learn from his peers (Cohen 1994; Johnson and Johnson, 2009).

Characteristics of a learning environment should enable students to develop self-regulated learning, problem solving and collaborative learning. In particular, at the end of secondary vocational education students have to be able to solve problems out of their daily (vocational) life in a self-regulated way, individually and with support of each other.

\subsubsection{Adaptive Learning Support}

Vocational education is characterized by an ever more heterogeneous population of students. They differ in cultural background, language, interests, values, socioeconomic status, and academic readiness. To meet the needs of these diverse students, the curriculum must adapt to the background, strengths, and interests of the individual student (De Bruijn and Leeman, 2011; Gardner, 2006; Tomlinson and Germundson 2007). This implies that there is a need for an adaptive learning environment that is supportive, varied, meets preferences and needs of students, and at the same time offers learning tasks that are challenging and attractive both on an individual and a collective level.

Strategies of adapting education to meet individual needs are an integral part of an educational approach that tries to improve the learning of all students (Tomlinson and Javius, 2012). Tomlinson's definition of differentiation clarifies its integral approach: " $\ldots$ an approach to teaching in which teachers proactively modify curricula, teaching methods, resources, learning activities and student products to address the diverse needs of individual students and small groups of students to maximize the learning opportunities for each student in a classroom" (1999, p. 121). This also implies assessment for learning throughout the learning process, contributing to the improvement of the learning processes in a continuous way (Brown, 2004; Tomlinson, 1999).

The integral part of adaptive learning support is clear when we consider the link with the key competences self-regulated learning, problem solving and collaborative learning. Teachers must be able to provide the kind of coaching that offers appropriate structure and trust, that stimulates students to self-regulate their own learning by providing differentiated help, communicating clear expectations and offering appropriate guidance (Jang et al., 2010; Kirschner et al., 2006; Mouratidisa et al., 2013; Sierens et al., 2009; van Merriënboer and Kirschner, 2013; Vansteenkiste et al., 2012). Self-assessment, as an important student skill in 
order to become a self-regulated learner, focusses on the improvement of the learning process. Self-assessment skills for learning require appropriate guidance and need to be explicitly taught as well (Boud et al., 1999; Brown and Harris, 2014; Harris and Brown, 2013). Winters (2012) highlighted that the most suitable guidance conversation must be dialogical, which implies that it stimulates and supports students to reflect on their own performance and learning. This is in line with perceptions of teachers and teacher educators in vocational education who emphasized the importance of setting up reflective dialogues with their students in order to build up self-regulation competences (Placklé et al., 2013). Reflective dialogue with peers is related to student engagement and the development of reflective consciousness (Richards and Richards, 2013).

\subsubsection{A Positive and Safe Learning Community}

The circle around the characteristics described above, visualizes a positive and safe learning culture as a prerequisite for learning (Hattie, 2009; Rubin, 2006). An optimal classroom culture is characterized by warm and supportive teacher-student and peer relationships, appropriate expressions of emotion, respectful communication and problem solving, strong interest and focus on tasks, building on students' strengths, abilities and needs, within a culture were individual differences are negotiable and common (Jennings and Greenberg, 2008; La Paro and Pianta, 2003). Such a culture is not a coincidental occurrence, but is intentionally built up and embedded in the structure of teaching and learning in every way (Shernoff, 2014).

The PoLEVE model visualizes interdependence of the various characteristics that together, and in interaction with each other, aim to improve learning, including engagement for learning, of every student to its maximum.

\subsection{Preferences in Vocational Education}

This research focusses on the voices of students, as they are the major stakeholders in the educational process. If teachers and teacher educators are willing to support the learning of students they must first hear what these students have to say about learning (Cook-Sather et al., 2014; Dahl, 1995; Könings et al., 2011b). Even more, when students are heard and their voices are taken seriously, they feel engaged to collaborate constructively in their education (Cook-Sather, 2006; Shernoff, 2014).

This study gives students an opportunity to express their educational preferences. With a newly developed questionnaire student preferences on the design of learning environments in secondary vocational education will be measured. This instrument is new compared with previous instruments as it is based on a recently developed holistic model for PLEs in vocational education, based on literature and corroborated by students, teachers and teacher educators (Placklé et al., 2013).

In this study the following research question will be addressed: How do students in vocational education prefer their learning environment to look like and is this in agreement with the characteristics of powerful learning environment in vocational education?

Based on previous research in other educational contexts (Könings, 2007), we hypothesize that students' preferences are mostly in line with guidelines described in the literature as beneficial for learning. In a previous qualitative study in secondary vocational education (Placklé et al., 2013) students strongly favoured authentic and challenging learning pathways. Students also preferred a stronger student 
voice. They preferred opportunities to practice self-regulated learning, problem solving and collaborative learning. The desirability of "dialogue" was highlighted. The desirability of differentiation was ambiguous. In other studies differentiation was not a preferable characteristic (Könings, 2007).

\section{Method}

\subsection{Participants}

Nine schools with vocational secondary education were invited to participate in this study. These schools had varied interests in PGS and varied in their innovative capacities (e.g., being involved in innovative projects) in general. One school dropped out because of a heavy workload. Three schools only offered vocational and technical education; the other schools also offered general education. The specific contexts of the schools varied widely. The schools varied in size (from 197 to 940 students) and in location. The schools represented a range of neighbourhoods (from province capitals to rural municipalities), public and private schools, both state and catholic. Student demographics also varied between schools, although all showed an extremely high percentage of students with low socio-economic status (mean $=66 \%$, $\min .52 \%$, max. $76 \%$ ).

The questionnaire was filled out by 544 students in the fifth, sixth and seventh year of secondary vocational education. Students were between 16 and 20 years old. The survey was completed during their regular lesson schedule, so the participation degree was $100 \%$ of the present students at that day. Schools had an option for a survey on paper $(n=205)$ or an online version $(n=339)$.

\subsubsection{Development of the IPoLEVE}

The IPoLEVE (Inventory on Powerful Learning Environments in Vocational Education) was developed in order to measure the students' perspective on PLEs in vocational education. Student-report data are most proximal to students' experiences of the class (Fulmer and Liang, 2013). In developing the IPoLEVE, we sought to measure eight dimensions of the model for PLEs in vocational education:

(1) Authentic and challenging content, (2) Self-regulated learning, (3) Collaborative Problem Solving, (4) Assessment for learning, (5) Differentiation, (6) and Coaching with subscales Structure and Trust, (7) Reflective dialogue teachers, and (8) Reflective dialogue peers.

We consider a positive and safe learning environment as a prerequisite of a PLE, which has to be built up in such a way that it intentionally supports teaching and learning in every way (Shernoff, 2014). Therefore, we did not measure this construct on a separate scale. A positive and safe learning environment refers to the quality of the relationships students have with their teachers and peers. The scale Coaching with its subscales Dialogue Teachers, Dialogue Peers and Trust refers to the importance of different kinds of supportive relationships in which students participate in a mutually caring, social arrangement with willing adults and peers, resulting in a positive and safe learning environment. Characteristics of a broader positive and safe learning environment were thus integrated within the different scales, e.g. "a culture where differences can be discussed" is placed under the scale "differentiation". 
For the operationalization of the dimensions, we started by examining existing instruments and the data of our qualitative research (Placklé et al., 2013). The IPoLEVE contains 53 items: 24 items originate from the IPSEE (Könings et al., 2011a), 8 originate from the TSCQ (Belmont et al., 1988), 6 items from the VaSCoA-VI (Brown, 2008), and 3 items from the observation instrument of PLE in vocational education (de Bruijn et al., 2006). Based on our theoretical framework and our previous qualitative research (Placklé et al., 2013), we developed another 12 items in order to measure the characteristics of powerful learning environments in vocational education more completely.

For every item, students rate their preference ('I would like this to happen') on a five point Likert scale ranging from 1 (always) to 5 (almost never or never), except for the scales "Dialogue", where a four-point scale (from "often" to "almost never or never") was used, because of content reasons (the category "always" was not applicable here). For uniform interpretation of all scale scores, we recoded the scores to a proportional score from 0 to 1. Data were gathered in Spring 2013.

Confirmatory Factor Analysis (CFA) and Cronbach's Alpha were used to test the reliability of the instrument. We conducted Confirmatory Factor Analyses (CFA) using the program Lavaan in $-\mathrm{R}$.

After the final data collection was complete, we tested the reliability of all the scales. Descriptive statistics were conducted on what students' preferences on characteristics of the PoLEVE were.

The CFA results suggested that the model was a good fit for all scales, if three negatively formulated items were removed. When we removed the Scale Differentiation, we had a significant difference on the model (RMSEA $=.044$, CI RMSEA $=[.036,0.048]$, CFI $=.90$, SRMR $=.061)$.

Table 1: Scales IPoLEVE

\begin{tabular}{|c|c|c|c|}
\hline Model & (Sub)scale & Description & $\begin{array}{c}\text { Sample items } \\
\text { "In a PGS course,..." }\end{array}$ \\
\hline $\begin{array}{l}\text { Learning } \\
\text { tasks }\end{array}$ & $\begin{array}{l}\text { Authentic and } \\
\text { challenging } \\
\text { (8 items) }\end{array}$ & $\begin{array}{l}\text { Extent to which the } \\
\text { learning } \\
\text { environment is } \\
\text { meaningful, } \\
\text { authentic and } \\
\text { challenging. }\end{array}$ & $\begin{array}{l}\text { “..., we explore real-life } \\
\text { problems out of daily } \\
\text { life or vocational } \\
\text { practice". } \\
\text { "..., I learn how to make } \\
\text { connections between } \\
\text { what I learn in PGS and } \\
\text { my daily life." }\end{array}$ \\
\hline \multirow{2}{*}{$\begin{array}{l}\text { Key } \\
\text { competences }\end{array}$} & $\begin{array}{l}\text { Self-regulated } \\
\text { learning } \\
\text { (8 items) }\end{array}$ & $\begin{array}{l}\text { Extent to which } \\
\text { students get } \\
\text { opportunities to take } \\
\text { control over their } \\
\text { own learning. }\end{array}$ & $\begin{array}{l}\text { “..., I have a voice in } \\
\text { what I want to learn.' } \\
\text { '...,I am given a lot of } \\
\text { responsibility.' }\end{array}$ \\
\hline & $\begin{array}{l}\text { Collaborative } \\
\text { problem } \\
\text { solving } \\
(6 \text { items })\end{array}$ & $\begin{array}{l}\text { Extent to which } \\
\text { students get } \\
\text { opportunities to } \\
\text { solve problems } \\
\text { together. }\end{array}$ & $\begin{array}{l}\text { '..., we solve problems } \\
\text { together.' } \\
\text { '..., we discuss the } \\
\text { strategy to complete the } \\
\text { learning tasks.' }\end{array}$ \\
\hline $\begin{array}{l}\text { Adaptive } \\
\text { learning }\end{array}$ & $\begin{array}{l}\text { Assessment } \\
\text { for learning }\end{array}$ & $\begin{array}{l}\text { Extent to which } \\
\text { evaluation }\end{array}$ & $\begin{array}{l}\text { '.., the teacher gives } \\
\text { me a lot of feedback on }\end{array}$ \\
\hline
\end{tabular}




\begin{tabular}{|c|c|c|c|}
\hline \multirow[t]{6}{*}{ support } & (6 items) & $\begin{array}{l}\text { contributes to the } \\
\text { improvement of } \\
\text { learning in a } \\
\text { continuous way. }\end{array}$ & $\begin{array}{l}\text { my learning tasks and } \\
\text { tests' } \\
\text { '.... I use the feedback } \\
\text { to improve my learning' }\end{array}$ \\
\hline & $\begin{array}{l}\text { Differentiation } \\
\text { (6 items) }\end{array}$ & $\begin{array}{l}\text { Extent to which } \\
\text { students get } \\
\text { opportunities to } \\
\text { perform learning } \\
\text { tasks that address } \\
\text { their needs to } \\
\text { maximize learning. }\end{array}$ & $\begin{array}{l}\text { '..., my learning tasks } \\
\text { are adapted to my needs, } \\
\text { interest or talents.' } \\
\text { '..., I work with own } \\
\text { learning goals.' }\end{array}$ \\
\hline & \multirow[t]{2}{*}{$\begin{array}{l}\text { Coaching / } \\
\text { Structure } \\
\text { (4 items) }\end{array}$} & $\begin{array}{l}\text { Extent to which } \\
\text { students get } \\
\text { appropriate structure } \\
\text { to support their self- } \\
\text { regulated learning. } \\
\end{array}$ & $\begin{array}{l}\text { '..., the expectations are } \\
\text { clear.' } \\
\text { '..., the teacher shows } \\
\text { me how I can solve } \\
\text { problems on my own.' }\end{array}$ \\
\hline & & $\begin{array}{l}\text { Extent to which the } \\
\text { relationship with } \\
\text { their teacher is built } \\
\text { on trust. }\end{array}$ & $\begin{array}{l}\text { 'My teacher believes in } \\
\text { me' } \\
\text { 'My teacher takes care } \\
\text { of me." }\end{array}$ \\
\hline & $\begin{array}{l}\text { Coaching/ } \\
\text { Reflective } \\
\text { dialogue } \\
\text { teachers } \\
\text { (5 items) }\end{array}$ & $\begin{array}{l}\text { Extent to which a } \\
\text { reflective dialogue } \\
\text { with peers is part of } \\
\text { the learning and } \\
\text { (vocational) identity } \\
\text { development } \\
\text { process. }\end{array}$ & $\begin{array}{l}\text { 'I talk with my teachers, } \\
\text { about what I have } \\
\text { learned of experiences } \\
\text { during lessons' } \\
\text { 'I talk with my teachers } \\
\text { about 'what kind of } \\
\text { person I am ( my talents, } \\
\text { my interests, my needs)' }\end{array}$ \\
\hline & $\begin{array}{l}\text { Coaching/ } \\
\text { Reflective } \\
\text { dialogue } \\
\text { peers } \\
\text { (5 items) }\end{array}$ & $\begin{array}{l}\text { Extent to which a } \\
\text { reflective dialogue } \\
\text { with peers is part of } \\
\text { the learning and } \\
\text { (vocational) identity } \\
\text { development } \\
\text { process. }\end{array}$ & $\begin{array}{l}\text { 'I talk with my peers, } \\
\text { about what I have } \\
\text { learned of experiences } \\
\text { during the lessons.' } \\
\text { 'I talk with my peers, } \\
\text { about what kind of } \\
\text { person I am ( my talents, } \\
\text { my interests, my } \\
\text { needs).' }\end{array}$ \\
\hline
\end{tabular}

The model, without Differentiation, fits good to very good, depending on the index. When we add the Scale Differentiation, the model stays suitable (RMSEA $=.046$, CI RMSEA $=[.042, .049], \mathrm{CFI}=.87, \mathrm{SRMR}=.071)$. We decided to keep the scale Differentiation without the reversed items.

Reliability analyses were performed on each of the scales. The internal consistencies of the scales were generally high. The IPoLEVE scale Authentic and Challenging shows an internal consistency of .79, Self-regulation of .83, Collaborative problem-solving of .90, Evaluation for learning of .90, Differentiation of .79, Coaching Structure / Trust of .95, Coaching Reflective Dialogue Teachers of .90, and Coaching Reflective Dialogue Peers of .92. 


\subsection{Data Analyses}

Missing data occur between 3\% and 6\% in the final data. If students did not respond on an item, the online tool gave them a reminder. So, missing data only occur in the written version, where some items were skipped by the students. For the learning environment characteristics a limited amount of data was missing ranging from $2.8 \%$ missing values for the scale measuring self-regulated learning, up to $5.6 \%$ for the differentiation scale. In order to reduce the biasing impact that these missing data can have on the results, we used multiple imputation techniques (James et al., 2004). Multiple imputation, as an appropriate model that incorporates random variation, was used on scales to take advantage of the existing correlations and increased testing power. Through multiple imputation, ten datasets without missing data were generated. Descriptive statistics were conducted to address what student preferences towards their learning environments are. In order to test whether preferences were significantly different from the neutral score of .50, we could not use one sample t-tests because of the multiple-imputation. Analyses were therefore performed separately on the ten datasets, resulting in an average value across the sets (Litle and Rubin, 2002) and variance estimate V $\beta$ reflecting variation within and between imputations. The normality approximation is valid due to the big sample size.

\section{Results}

How do students in vocational education prefer their learning environment in PGS courses, and is this in line with the characteristics of powerful learning environments in vocational education as described in the literature and in the PoLEVEmodel?

Table 2 presents the descriptive results for the preference scores of the different scales of the IPoLEVE. Results show that students prefer challenging and authentic learning tasks, self-regulated learning, collaborative problem solving, assessment for learning, and structure and trust $(p<.01, d=$ between .48 and .66$)$. These are medium effect sizes (Cohen, 1988). The preference score referring to 'Differentiation' is less explicit (mean .53) but significant, with a small effect size $(p<.01, d=.12)$. 'Reflective dialogue with teachers' and 'Reflective dialogue with Peers' was significantly not a preferable characteristic of PLEs in vocational education. In sum, the preferences of students are in line with the characteristics of PLEs in vocational education, although with only a small effect size regarding 'differentiation'. Setting up a reflective dialogue, either with teachers or with peers, was not a preferable characteristic. 
Table 2: Mean preference scores and standard error of scales IPoLEVE

\begin{tabular}{|l|r|r|r|l|}
\hline Scales & Mean & \multicolumn{1}{|c|}{ SEM } & \multicolumn{1}{c|}{$\mathrm{p}$} & $\mathrm{d}$ \\
\hline Authentic and challenging & .70 & .01 & .000 & $0.66^{*}$ \\
\hline Self-regulated learning & .71 & .01 & .000 & $0.55^{*}$ \\
\hline Collaborative problem solving & .70 & .01 & .000 & $0.62^{*}$ \\
\hline Assessment for learning & .64 & .01 & .000 & $0.48^{*}$ \\
\hline Differentiation & .53 & .01 & .002 & $0.12^{*}$ \\
\hline Coaching Structure /Trust & .73 & .01 & .000 & $0.61^{*}$ \\
\hline Coaching Reflective Dialogue Teachers & .45 & .02 & .001 & $0.14^{*}$ \\
\hline Coaching Reflective Dialogue Peers & .38 & .00 & .000 & $1.00^{*}$ \\
\hline
\end{tabular}

Notes. $\mathrm{N}=532$. Final variance estimate $\mathrm{V} \beta$ reflecting variation within and between imputations, neutrality .50, all differences are significant alpha $<.01$ (Bonferonni corrected).

\section{Discussion}

Student preferences are in line with most characteristics of the model of PLEs in vocational education. Students themselves are asking for challenging learning pathways; they want to widen their horizons and take their learning into their own hands. They prefer to solve authentic problems with each other's support. The desirability of differentiation was significant, but only with a small effect size. In our qualitative research (Placklé et al., 2013), students were struggling with the "fairness" of differentiation and their attitudes towards differentiation were ambiguous. The operalisation of differentiation in positive items, for example - my learning tasks are adapted to my needs, interest or talents - could be an explanation for the desirability towards the characteristic. Students expressed their preference for characteristics related to adaptive learning support as well: Evaluation for learning, and Coaching that offers structure and trust. Teachers accepting differences between students more often tend to consider differences as an integral part of learning (Hattie, 2005). Building on a class climate where differences are common and are discussible, could improve the students' perception of differentiation as well.

Remarkably, setting up a reflective dialogue with teachers is not a preferred characteristic, although it is a key element of coaching. High-quality student guidance, through a reflective dialogue between teachers and students, requires competences of teachers to talk with their students instead of talking to them. This implies a dialogical shift towards student-centered positioning. Because many students do not have these experiences yet (Winters et al., 2011), they might not appreciate the characteristic at this moment.

In this study, the researchers have given a voice to vocational students about their education. In this way, it contributes to the conceptualization of teaching and learning as a collaborative process (Corbett and Wilson, 1995; Cook-Sather, 2002) with students.

Previous studies indicated that the overall learning environment may be the most salient variable influencing engagement (Shernoff, 2010). Almost all research on teaching and learning conceptualizes learning as a property of the individual learner. However, characteristics of the learning environment seem to be an even more important factor in the propensity to engage in learning than characteristics of the individual (Shernoff, 2010). It is up to teachers and teacher educators to further 
develop teachers' competences for creating learning environments that take into account students' preferences on teaching in learning in vocational education (Cook-Sather et al., 2014). Teachers are challenged to redesign vocational learning pathways in order to raise students' engagement substantially. Sharing this responsibility with students might help to make this process more effective.

\subsection{Suggestions for further research}

In this study we found evidence that students prefer most characteristics of PLEs in vocational education. The ultimate aim is to improve student engagement and achievement. A future study would be beneficial to investigate the extent to which the characteristics of powerful learning environments are implemented in relation to student engagement and student achievement. 


\section{References}

Aleamoni, L.M. (1999). Student rating myths versus research facts from 19241998. Journal of Personnel Evaluation in Education, 13(2), 153-166.

Belmont, M., Skinner, E., Wellborn, J., \& Connell, J. (1988). Teacher as Social Context Questionnaire: A measure of student perceptions of teacher provision of involvement, structure, and autonomy support. University of Rochester: New York.

Boeckaerts, M., \& Niemvirta, M. (2000). Self-regulated learning: Finding a balance between learning goals and ego-protective goals. In Boekaerts, M., Pintrich, P.R. \& Zeidner, M. (Eds.). Handbook of Self-Regulation (pp. 417450).London, Academic Press.

Boud, D., Cohen, R., \& Sampson, J. (1999). Peer learning and assessment. Assessment \& Evaluation in Higher Education, 24(4) 413-426.

Brown, G.T.L. (2004). Teachers' conceptions of assessment: implications for policy and professional development. Assessment in Education: Principles, Policy \& Practice, 11(3), 301-318.

Brown, G.T.L. (2008). Students' conceptions of assessment (SCoA) inventory. Unpublished test. Auckland, NZ: University of Auckland.

Brown, G.T.L., \& Harris, L.R. (2014). The future of self-assessment in classroom practice: Reframing self-assessment as a core competency. Frontline Learning Research. 2 (1), 22-30. doi: 10.14786/flr.v2i1.2.

Centre for Applied Educational Research. (2002). Middle Years Research and Development (MYRAD). Project Executive Summary February-December 2001. A Report to the Learning \& Teaching Innovation. Division, Department of Education \& Training. Melbourne: The University of Melbourne.

Cleary, T.J., \& Zimmerman, B.J. (2004). Self-regulation empowerment program: A school-based program to enhance self-regulated and self-motivated cycles of student learning. Psychology in the Schools, 41(5), 537-550.

Cohen, E.G. (1994). Restructuring the classroom: Conditions for productive small groups. Review of Educational Research, 64 (1), 1-35.

Cole, P. (2006). Reforming Year 9: Propositions for School Policy and Practice, Occasional Paper 96. Melbourne: Centre for Strategic Education.

Cool-Sather, A. (2002). Authorizing Students' Perspectives: Toward Trust, Dialogue, and Change in Education. Educational Researcher. 31, (4), 3-14.

Cook-Sather, A. (2006). Sound, Presence, and Power: Student Voice in Educational Research and Reform. Curriculum Inquiry, 36, 359-390.

Cook-Sather, A., Bovill, C., \& Felten, P. (2014). Engaging Students as Partners in Teaching and Learning: A Guide for Faculty. San Francisco: Jossey-Bass.

Corbett, H. D. \& Wilson, R. L. (1995). Make a difference with, not for, students: A plea for researchers and reformers. Educational Researcher, 24 (5), 12-17.

Dahl, K. (1995). Challenges in understanding the learner's perspective. Theory into Practice, 43 (2), 124-130.

de Bruijn, E. (2012). Teaching in innovative vocational education in the Netherlands. Teachers and Teaching: Theory and Practice, 18, 637-653, doi:10.1080/13540602.2012.746499.

de Bruijn, E., \& Leeman, Y. (2011). Authentic and self-directed learning in vocational education: Challenges to vocational educators. Teaching and Teacher Education, 27(4), 694-703.

de Bruijn, E., Leeman, Y., \& Overmaat, M. (2006). Authentiek en zelfgestuurd 
leren in het mbo. Pedagogiek, 26(1), 45-63.

De Corte, E. (1990). Towards powerful learning environments for the acquisition of problem solving skills. European Journal of Psychology of Education, $5(1), 5-19$.

De Corte, E. (2003). Designing learning environments that foster the productive use of acquired knowledge and skills. In E. De Corte, L.Verschaffel, N. Entwistle, \& J. J. G. Van Merriënboer (Eds.), Powerful learning environments: Unravelling basic components and dimensions (pp. 21-33). Oxford: Elsevier Science.

Doll, B., Spies R.A, Champion, A., Guerrero, C., Dooley, K., \& Turner, A. (2010). The Class Maps Survey: A Measure of Middle School Science Students' Perceptions of Classroom Characteristics. Journal of Psycho educational Assessment, 28(4), 338-348.

Fredricks, J.A. Blumenfeld, P.C., \& Paris, A.H. (2004). School engagement: Potential of the concept, state of the evidence. Review of Educational Research, 74, 59-109.

Fullarton, S. (2002). Student engagement with school: individual and school-level influences. LSAY Research Reports. Longitudinal surveys of Australian youth research report. http://research.acer.edu.au/lsay_research/31. Accessed 25 October 2014.

Fulmer, G.W., \& Liang, L.L. (2013). Measuring Model-Based High School Science Instruction: Development and Application of a Student Survey. Journal of Science Education and Technology, 22, 37-46. doi: 10.1007 /s10956-012-9374-z.

Gardner, H. (2006). Multiple intelligences: New horizons in theory and practice. New York: Basic Books.

Harris, L.R., \& Brown, G. T.L. (2013). Opportunities and obstacles to consider when using peer- and self-assessment to improve student learning: Case studies into teachers' implementation. Teaching and Teacher Education, 36, 101-111. doi:10.1016/j.tate.2013.07.008.

Hartigan, J.A., \& Wong, M.A. (1979). Algorithm AS 136: A K-Means Clustering Algorithm. Journal of the Royal Statistical Society. Series C (Applied Statistics), 28(1), 100-108.

Hattie (2005). What is the nature of evidence that makes a difference to learning? Paper presented at the ACER conference, Melbourne. Website http:// research.acer.edu.au/research_conference_2005/7. Accessed 29 October 2014.

Hattie, J. (2009). Visible Learning: A Synthesis of over 800 Meta-Analyses relating to Achievement. London: Routledge.

Jang, H., Reeve, J., \& Deci, E.L. (2010). Engaging students in learning activities: It's not autonomy support or structure, but autonomy support and structure. Journal of Educational Psychology, 102, 588-600. doi:10.3102/0034654308 325693.

Jennings, P.A., \& Greenberg, M.T. (2009). The prosocial classroom: Teacher social and emotional competence in relation to student and classroom outcomes. Review of Educational Research, 79, 491-525.

Johnson, D.W., \& Johnson, F. (2009). Joining together: Group theory and group skills (10th ed.). Boston: Allyn \& Bacon.

Kannapel, P.J., \& Clements, S.K. (2005). Inside the black box of high performing high-poverty schools. Lexington, KY: The Prichard Committee for Academic Excellence. 
Kicken, W., Brand-Gruwel, S., van Merriënboer, J.J.G., \& Slot, W. (2009). Design and evaluation of a development portfolio: How to improve students' selfdirected learning skills. Instructional Science, 37, 453-473. doi: 10.1007/ s11251-008-9058-5.

Kirschner, P.A., Sweller, J., \& Clark, R.E. (2006). Why minimal guidance during instruction does not work: An analysis of the failure of constructivist, discovery, problem-based, experiential, and inquiry-based teaching. Educational Psychologist, 41, 75-86.

Könings, K.D., Brand-Gruwel, S., \& van Merriënboer, J.J.G. (2005). Towards more powerful learning environments through combining the perspectives of designers, teachers and students. British Journal of Educational Psychology, 75(4), 645-660. doi:10.1348/000709905X43616

Könings, K. D., Brand-Gruwel, S., \& van Merriënboer, J.J. G. (2011a). The Match between Students' Lesson Perceptions and Desires: Relations with Student Characteristics and the Importance of Motivation. Educational Research, 53, 439-457. doi:10.1080/00131881.2011.625155.

Könings, K.D., Brand-Gruwel, S., \& van Merriënboer, J.J.G. (2011b). Participatory Instructional redesign by students and teachers in secondary education: Effects on perceptions of instruction. Instructional Science, 39, 737-762. doi:10.1007/s11251-010-9152-3.

Könings, K.D. Seidel, T. van Merriënboer, J.J.G. (2014). Participatory design of learning environments: integrating perspectives of students, teachers, and designers. Instructional Sciences. 42(1), 1-9. doi:10.1007/s11251-013-9305-2

La Paro, K.M., \& Pianta, R. (2003). CLASS: Classroom Assessment Scoring System. Charlottesville: University of Virginia.

Litle, R.J., \& Rubin, D.B. (2002). Statistical analysis with missing data. $2^{\text {nd }}$ ed. New York: Wiley.

Marks, H. M. (2000). Student engagement in instructional activity: Patterns in the elementary, middle, and high school years. American Educational Research Journal, 37,153 - 184. doi: 10.3102/00028312037001153.

Mouratidisa, A., Vansteenkiste, M., Michouc, A., Lens, W. (2013). Perceived structure and achievement goals as predictors of students' self-regulated learning and affect and the mediating role of competence need satisfaction. Learning and Individual Differences. 23, 179-186. doi: 10.1016/j.lindif. 2012.09.001.

Nelson, L.M. (1999). Collaborative problem solving. In C.M. Reigeluth (Ed.), Instructional design theories and models: A new paradigm of instructional theory (pp. 241-267). Mahwah, NJ: Lawrence Erlbaum Associates, Inc.

OECD. (2013). PISA 2012 Results: Excellence Through Equity: Giving Every Student the Chance to Succeed. (Volume II), PISA, OECD Publishing. doi: 10.1787/9789264201132-en.

Placklé, I., Engels, N., Libotton, A., Struyven, K, Könings, K. D. \& van Merriënboer, J.J.G. (2013). Characteristics of powerful learning environments in secondary vocational education as perceived by teacher educators, teachers and students. Paper presented at the conference JVET, Oxford.

Placklé, I., Könings, K, Engels, N., Jacquet, W., Struyven, K., Libotton, A., van Merriënboer, J.J.G. (2015). Looking through the Eyes of Students in Vocational Education, from their Present Learning Environments into the Future. Paper will be presented at AERA, Chicago.

Peugh, J.L., \& Enders, C.K. (2004). Missing Data in Educational Research: A 
Review of Reporting Practices and Suggestions for Improvement. Review of Educational Research. 74(4), 525-556.

Richards, R. W. \& Richards, L.M (2013). Sponges do not make their own water: student engagement through dialogue and the development of reflective consciousness. Reflective Practice: International and Multidisciplinary Perspective. 14(6), 774-786. doi:10.1080/14623943.2013.836083.

Rumberger, R. (2012). Dropping out. Why students drop out of high school and what can be done about it. USA: Harvard University Press.

Sears, D. A. \& Reagin, J. M. (2013). Individual versus collaborative problem solving: Divergent outcomes depending on task complexity. Instructional Science. 41( 6), 1153-1172. doi: 10.1007/s11251-013-9271-8.

Shernoff, D. J. (2010). The experience of student engagement in high school classrooms: Influences and effects on long-term outcomes. Saarbruken: Lambert Academic.

Shernoff, D. J. (2014). Optimal Learning Environments to Promote Student Engagement. Advancing Responsible Adolescent Development, New York: Springer. doi:10.1007/978-1-4614-7089-2.

Sierens, E., Vansteenkiste, M., Goossens, L., Soenens, B., \& Dochy, F. (2009). The synergistic relationship of perceived autonomy support and structure in the prediction of self-regulated learning. British Journal of Educational Psychology, 79, 57-68. doi: 10.1348/000709908X304398.

Smith, P., \& Blake, D. (2006). Facilitating learning through effective teaching: At a glance. Adelaide: National Centre for Vocational Education Research. Accessed 29 October 2014. http://www.ncver.edu.au/publications/1660.html.

Smyth, J., \& Fasoli, L. (2007). Climbing over the Rocks in the Road to Student Engagement and Learning in a Challenging High School in Australia. Educational Research, 49(3), 273-295. doi:10.1080/00131880701550565.

Tomlinson, C.A. (1999). The differentiated classroom responding to the needs of all learners. Alexandria, Virginia: Association for Supervision and Curriculum Development.

Tomlinson, C.A., \& Germundson, A. (2007). Teaching as Jazz. Educational Leadership, 64(8), 27-31.

Tomlinson, C.A., \& Javius, E. L. (2012). Teach Up for Excellence. Educational Leadership, 69(5), 28-33.

van Beek, J.A., \& de Jong, F.P.C.M., Minnaert, A.E.M.G., Wubbels, Th., (2014) Teacher practice in secondary vocational education: Between teacherregulated activities of student learning and student self-regulation. Teaching and Teacher Education, 40, 1-9. doi: 10.1016/j.tate.2014.01.005.

van Merriënboer, J. J. G., \& Paas, F. (2003). Powerful learning and the many faces of instructional design: Toward a framework for the design of powerful learning environments. In E. de Corte, L. Verschaffel, N. Entwistle, \& J.J.G. van Merriënboer (Eds.), Unravelling basic components and dimensions of powerful learning environments (pp. 3-20). Oxford: Elsevier Science.

van Merriënboer, J. J. G., \& Kirschner, P. A. (2012). Ten steps to complex learning (Second edition). New York: Taylor \& Francis.

Vansteenkiste, M., Sierens, E., Goossens, L., Soenens, B., Dochy, F., Mouratidis, A., Aelterman, N., Haerens, L., \& Beyers, M. (2012). Identifying configurations of perceived teacher autonomy support and structure: Associations with self-regulated learning, motivation and problem behavior. Learning and Instruction, 22, 431-439. 
Walsh, L. \& Black, R. (2009). Overcoming the barriers to engagement and equity for all students. Paper presented at Australian Curriculum Studies Association. Biennial Conference Curriculum: a national conversation, Canberra, 2-4 October.

Willms, J.D. (2003). Student engagement at school: A sense of belonging and participation: Results from PISA 2000. Paris: Organisation for Economic Cooperation and Development.

Winters, A., Meijers, F., Harlaar, M., Strik, A., Kuijpers, M., \& Baert, H. (2013). The narrative quality of career conversations in vocational education. Journal of Constructivist Psychology, 26(2), 115-126.

Yazzie-Mintz, E. (2007). Voices of students on engagement: A report on the 2006 high school survey of student engagement. Bloomington: Center for Evaluation \& Education Policy. 